\title{
HARGA DIRI DAN KUALITAS HIDUP PADA PASIEN DENGAN CHRONIC KIDNEY DISEASE YANG MENJALANI HEMODIALISIS
}

\author{
Kurniasih Ayu Archentari, Vista Gasela, Nadya Ariyani Hasanah Nuriyyatiningrum, \\ Aulia Iskandarsyah
}

Fakultas Psikologi Universitas Padjadjaran

J1. Raya Bandung Sumedang KM 21, Jatinangor, Indonesia 45363

aarchentari@yahoo.com

\begin{abstract}
Patients with a chronic kidney disease encounter medical as well as psychological problems. They have to adjust to the daily changes in life as consequences of the required treatment. The need to take medication regularly, hemodialysis treatment, and reduce mobility because of limitation of physical abilities may cause distress and often impact on their self-esteem. This study aimed to investigate the correlation of self-esteem to quality of life on patients with chronic kidney disease who undergo hemodialysis. The study population is patients who join "Komunitas Hidup Ginjal Muda", a community of young people with kidney disease in the social media (Facebook) which has 371 members. The incidental sampling technique was applied and resulted in 34 patients joined the study as study participants. The Rosenberg Self-Esteem Scale and the Kidney Disease Quality of Life Short Form (version 1.3) were used to collect data. The results of product moment correlation analysis showed that there was a positive and significant correlation between self-esteem and quality of life among chronic kidney disease patients who undergo hemodialysis $(r=.417 ; p=.014)$.
\end{abstract}

Keywords: self-esteem; hemodialysis; chronic kidney disease; quality of life; community

\begin{abstract}
Abstrak
Pasien yang mengalami chronic kidney disease (CKD) tidak hanya mengalami masalah kesehatan, melainkan juga masalah psikologis. Pasien yang mengalami sakit ginjal kronis harus menyesuaikan diri dengan perubahan rutinitas dalam hidupnya karena kewajiban akan pengobatannya. Keharusan untuk meminum obat secara rutin, terapi hemodialisis, dan mobilitas yang berkurang karena terbatasnya kemampuan fisik membuat mereka terkadang mengalami stres dan pada akhirnya mempengaruhi harga diri mereka. Penelitian ini bertujuan untuk mencari hubungan antara harga diri dengan kualitas hidup pada pasien chronic kidney disease yang menjalani hemodialisis. Populasi dalam penelitian ini adalah pasien chronic kidney disease yang menjalani hemodialisis yang terdaftar sebagai anggota Komunitas Hidup Ginjal Muda, sebuah komunitas ginjal di media sosial Facebook, dengan jumlah 371 pasien. Mempertimbangkan besarnya jumlah pasien yang ada dan kesediaan pasien, maka peneliti menggunakan teknik sampling insidental dan mendapatkan sejumlah 34 orang sampel penelitian. Harga diri diukur menggunakan Skala Self-Esteem Rosenberg dan kualitas hidup diungkap dengan Skala Kidney Disease Quality of Life Short Form, versi 1.3. Uji hipotesis korelasi menggunakan analisis korelasi Pearson. Terdapat korelasi positif yang signifikan antara harga diri dengan kualitas hidup pada pasien $C K D$ yang menjalani hemodialisis $(r=0,417 ; p=0,014)$.
\end{abstract}

Kata kunci: harga diri; kualitas hidup; chronic kidney disease; hemodialisis; komunitas

\section{PENDAHULUAN}

Chronic kidney disease (CKD) adalah keadaan penurunan fungsi ginjal secara progresif serta permanen yang dapat diakibatkan oleh berbagai macam penyakit (Putri \& Yadi, 2014). Ahmed \& Lowder (dalam Gooz, 2012) menyebutkan bahwa
CKD didefinisikan sebagai laju filtrasi glomerulus (GFR) di bawah $60 \mathrm{ml} /$ menit per $1,73 \mathrm{~m} 2$ selama 3 bulan atau lebih. CKD biasanya berawal dari adanya penurunan yang mantap dalam fungsi ginjal, seperti yang ditemukan dalam hubungan timbal balik dari kadar serum kreatinin dan waktu. Guna menangani 
keadaaan tersebut, salah satu bentuk intervensi medis yang dilakukan adalah hemodialisis. Hemodialisis (Gooz, 2012) adalah sebuah proses pemindahan cairan dan mengatasinya melalui sebuah membran semi permeabel dalam dialisat dengan melewati darah melalui ginjal buatan. Hemodialisis paling sering dilakukan pada pasien tiga kali seminggu dalam jangka waktu 3 hingga 4 jam (Conventional Hemodialysis - CHD), tetapi juga dapat dilakukan secara lebih pelan dalam sehari atau semalam (Nocturnal Hemodialysis - NHD).

Data yang didapat dari Indonesian Renal Registry (IRR) (2014), suatu program dari Perkumpulan Nefrologi Indonesia (PERNEFRI), menunjukkan bahwa adanya peningkatan pada jumlah pasien, terutama pasien aktif selama tahun 2007 hingga 2014. Dalam kurun waktu tersebut, terdapat peningkatan lebih dari 6 kali lipat dari jumlah awalnya.

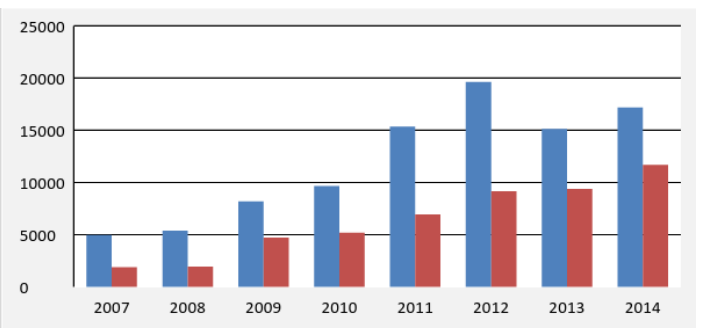

Gambar 1. Tabulasi pasien baru dan pasien aktif $C K D$ yang menjalani Hemodialisis di Indonesia tahun 2007-2014

Berdasarkan data Riskedas (Riset Kesehatan Dasar) tahun 2013, pasien yang memiliki CKD di Indonesia sebesar 0,2\%. Provinsi Jawa Barat sendiri memiliki persentase pasien ginjal kronis sebesar $0,3 \%$. Prevalensi pasien ginjal kronis meningkat pada usia dewasa madya. Pada usia 35-44 tahun sebesar 0,3\%, umur 45-54 tahun sebesar 0,4\%, umur 55-74 tahun sebesar $0,5 \%$, dan paling tinggi pada kelompok umur di atas 75 tahun yaitu $0,6 \%$. Terdapat perbedaan jenis kelamin dalam menentukan prevalensi pasien ginjal kronis. Laki-laki lebih tinggi prevalensinya daripada perempuan yaitu $0,3 \%$ dan perempuan $0,2 \%$. Masyarakat pedesaan memiliki prevalensi $0,3 \%$, tidak bersekolah $0,4 \%$, wiraswasta dan nelayan/buruh/petani $0,3 \%$. Berdasarkan hal tersebut maka, dapat dilihat bahwa CKD cukup banyak diderita oleh masyarakat Indonesia.

Pasien dengan CKD tidak hanya mengalami masalah fisik, melainkan juga psikologis. Para pasien dengan CKD mengalami penyakit ini secara menahun. Pasien mengalami gangguan berkemih, keletihan berlebihan, sulit tidur, nafsu makan menurun, bengkak pada kaki, kram otot, maupun disfungsi ereksi (Alam \& Hadibroto, 2007). Walaupun demikian, efek dari pengobatan yang bertahun-tahun tersebut tidak hanya menimbulkan banyak efek fisik namun juga psikologis.

Pasien dengan CKD rentan mengalami berbagai macam masalah psikologis yang pada akhirnya menurunkan kualitas hidupnya. Berdasarkan penelitian yang dilakukan oleh Lew \& Piraino (2005), pasien dengan CKD merasa tidak memiliki harapan, cemas, khawatir masalah keuangan, kehilangan fungsi seksual, beban keluarga, dan kehilangan kemandirian. Sebanyak 25\% dari sampel pasien dengan CKD yang menjalani hemodialisis ternyata juga mengalami depresi karena kesulitan dalam menyesuaikan rutinitas dan kehidupan baru setelah harus menjalani kewajiban hemodialisis.

Sebagai pasien dengan penyakit kronis, pasien dengan CKD mengalami banyak hal dalam dirinya. Babatunde \& Forsyth (2015) menemukan bahwa orientasi kesehatan pasien memiliki hubungan yang penting dengan kualitas hidup. Kualitas hidup merupakan salah satu tema penting dalam kehidupan individu dengan gagal ginjal kronik yang menjalani hemodialisis. Dipaparkan bahwa tema kualitas hidup banyak dibahas karena dalam kondisi sakit 
tersebut, pasien mengalami perubahan yang dramatis dalam hidupnya, banyak pembatasan yang harus ditaati, kesulitan untuk beraktivitas atau melakukan pekerjaan rumah tangga. Hal tersebut dijelaskan dalam penelitian yang dilakukan oleh Mardianingsih (2014) bahwa pasien mengalami perasaan-perasaan negatif seperti sedih, putus asa, menyesal, kecewa, dan malu. Pada akhirnya, perasaanperasaan negatif tersebut bisa menyebabkan depresi serta kecemasan. Penelitian yang dilakukan oleh William (dalam Farida, 2010) mengungkapkan bahwa kualitas hidup dipengaruhi oleh faktor psikologis seperti perasaan-perasaan negatif dan kecemasan.

Cruz, Andrade, Urrutia, Draibe, Martins, \& Sessol, (2011) menemukan bahwa kualitas hidup pada pasien yang menderita sakit ginjal mengalami penurunan. Penurunan tersebut mencakup fungsi fisik, peran fisik, dan komponen fisik yang dapat terjadi secara progresif pada setiap tingkat sakit ginjal terlebih pada tingkat awal. Padahal fakta yang diungkapkan oleh WHO (1997) menunjukkan bahwa kualitas hidup berdampak pada kesehatan fisik, kesehatan psikologis, tingkat kebebasan, hubungan sosial, keyakinan pribadi, dan hubungan mereka dengan lingkungan sekitar. Hal tersebut menunjukkan bahwa kualitas hidup merupakan variabel yang esensial untuk lebih mendalami bagaimana kondisi pasien dengan CKD.

World Health Organization atau WHO (1997) menjelaskan bahwa kualitas hidup adalah suatu persepsi individu yang memiliki sifat subjektif terhadap lingkungan dalam kehidupannya yang mencakup konteks nilai-nilai budaya, sosial, nilai sistem tempat tinggal mereka dan yang berhubungan dengan tujuan mereka. Salah satu komponen yang ada pada variabel kualitas hidup adalah komponen psikologis. Komponen psikologis menurut World Health Organization Quality of Life Instrument -
BREF (WHOQL-BREF, 1996) adalah komponen dalam diri manusia yang bersifat abstrak, dan tidak terlihat wujudnya, namun keberadaan psikologis ini tidak dapat dipungkiri keberadaannya. Hasil penelitian Shdaifat \& Manaf (2012) menunjukkan bahwa kualitas hidup adalah salah satu aspek penting yang menyumbang bagaimana individu dengan penyakit kronis menilai beban dalam hidupnya.

Mengingat berbagai pengalaman yang dimiliki oleh pasien dengan CKD yang bukan hanya berpengaruh pada keadaan fisik namun juga psikis, Poorgholami, Javadpour, Saadatmand, \& Jahromi (2015) memaparkan bahwa banyak penelitian yang menyebutkan pasien hemodialisis memiliki self-esteem yang lebih rendah dari yang sewajarnya dimiliki individu. Menurut James (dalam Baron \& Byrne, 2004) harga diri merupakan evaluasi terhadap diri sendiri. Harga diri merujuk dari sikap individu pada diri sendiri dalam jangka positif hingga negatif. Selain itu, dijelaskan pula oleh Demo (dalam Guindon, 2010) bahwa harga diri dipengaruhi oleh perubahan peran, harapan, penampilan, respon dari orang lain, dan karakter situasional lain.

Individu yang mengalami gagal ginjal kronis dan telah diwajibkan menjalani hemodialisis akan mengalami banyak perubahan dalam hidupnya. Perubahanperubahan tersebut, termasuk penyesuaian diri terhadap keterbatasan mobilitas, peran dalam masyarakat yang berkurang, dan produktivitas yang menurun, akan mempengaruhi kondisi psikologisnya. Selain itu, berbagai macam perubahan dalam hidup tersebut juga dapat berdampak pada persepsi individu mengenai hidupnya sekarang termasuk kualitas hidupnya dan persepsi tentang dirinya termasuk harga diri. Oleh sebab itu, peneliti menyimpulkan bahwa penting untuk dapat melihat bagaimana harga diri dan kualitas hidup pada pasien dengan 
CKD. Untuk itu, penelitian ini bertujuan untuk mencari hubungan antara harga diri dengan kualitas hidup pada pasien dengan CKD yang menjalani hemodialisis.

\section{METODE}

Penelitian ini menggunakan metode kuantitatif dan melibatkan dua variabel. Variabel prediktor yaitu harga diri akan diuji dengan menggunakan uji korelasi untuk menemukan hubungannya dengan variabel outcome yaitu kualitas hidup. Guna mengukur variabel harga diri, peneliti menggunakan skala Self-Esteem oleh Rosenberg (1965) yang telah diadaptasi dalam bahasa Indonesia. Sedangkan guna mengukur variabel kualitas hidup, peneliti menggunakan skala Kidney Disease Quality of Life Short Form, versi 1.3 oleh Hays dkk. (2000) yang telah diterjemahkan oleh peneliti ke dalam bahasa Indonesia.

Penelitian menggunakan analisis korelasi Pearson untuk menguji hubungan antara variabel prediktor (harga diri) dengan variabel outcome (kualitas hidup. Uji korelasi akan diproses dalam program Statistical Package for Social Science (SPSS) versi 21. Populasi dalam penelitian ini adalah pasien chronic kidney disease yang menjalani hemodialisis yang terdaftar sebagai anggota Komunitas Hidup Ginjal Muda, sebuah komunitas ginjal di media sosial Facebook, dengan jumlah 371 anggota (data hingga tahun 2016). Mempertimbangkan besarnya jumlah pasien yang ada dan kesediaan pasien, maka peneliti tidak dapat mengambil semua orang yang ada di dalam populasi. Kriteria sampel yang dipilih dalam penelitian ini adalah 1) mengalami chronic kidney disease yang sudah dinyatakan oleh hasil pemeriksaan dokter; 2) menjalani hemodialisis; 3) berusia di atas 20 tahun; 4) Warga Negara Indonesia; dan 5) bersedia terlibat dalam penelitian. Peneliti memilih teknik sampling insidental. Dari 371 anggota yang terdaftar di Komunitas
Hidup Ginjal Muda tahun 2016, terdapat 34 pasien yang bersedia menjadi sampel penelitian dengan cara mengisi skala secara online.

\section{HASIL DAN PEMBAHASAN}

Berdasarkan 34 sampel yang mengikuti penelitian ini, maka paparan demografi terdapat pada Tabel 1.

Tabel 1.

Data Demografi Subjek

\begin{tabular}{|c|c|c|c|}
\hline No & Jenis Identitas & Interval & $\begin{array}{l}\text { Jumlah } \\
\text { Sampel }\end{array}$ \\
\hline \multirow[t]{2}{*}{1} & \multirow[t]{2}{*}{ Jenis Kelamin } & Laki-Laki & 14 \\
\hline & & Perempuan & 20 \\
\hline \multirow[t]{9}{*}{2} & \multirow[t]{9}{*}{ Usia } & $\leq 20$ & 1 \\
\hline & & 21-25 tahun & 2 \\
\hline & & 26-30 tahun & 11 \\
\hline & & 31-35 tahun & 9 \\
\hline & & 36-40 tahun & 5 \\
\hline & & 41-45 tahun & 2 \\
\hline & & 46-50 tahun & 2 \\
\hline & & $51-55$ tahun & 0 \\
\hline & & 56-60 tahun & 2 \\
\hline \multirow[t]{3}{*}{3.} & \multirow[t]{3}{*}{ Status } & $\begin{array}{l}\text { Belum } \\
\text { Menikah }\end{array}$ & 11 \\
\hline & & Menikah & 22 \\
\hline & & $\begin{array}{l}\text { Janda / Duda } \\
\text { Cerai }\end{array}$ & 1 \\
\hline \multirow[t]{3}{*}{4.} & \multirow{3}{*}{$\begin{array}{l}\text { Frekuensi } \\
\text { Hemodialisis / } \\
\text { Minggu }\end{array}$} & 1 & 1 \\
\hline & & 2 & 29 \\
\hline & & 3 & 4 \\
\hline \multirow[t]{7}{*}{5.} & \multirow{7}{*}{$\begin{array}{l}\text { Rata-rata } \\
\text { penghasilan } \\
\text { keluarga / } \\
\text { bulan }\end{array}$} & $\begin{array}{l}\text { Tidak } \\
\text { Diketahui }\end{array}$ & 1 \\
\hline & & $<1$ juta & 1 \\
\hline & & 1-3 juta & 12 \\
\hline & & 3-5 juta & 4 \\
\hline & & 5-7 juta & 6 \\
\hline & & 7-9 juta & 5 \\
\hline & & $\geq 9$ juta & 5 \\
\hline \multirow[t]{2}{*}{6.} & \multirow{2}{*}{$\begin{array}{l}\text { Kerutinan } \\
\text { Hemodialisis }\end{array}$} & Rutin & 34 \\
\hline & & Tidak rutin & 0 \\
\hline
\end{tabular}

Sebelum dilakukan uji hipotesis, Skala Harga Diri diuji reliabilitas konsistensi internal menggunakan Cronbach's Alpha $\left(\alpha=0,743 ; r_{i t}=-0,077-0,595\right)$ begitu pula dengan Skala Kualitas Hidup $(\alpha=0,961$; $\left.r_{i t}=0,048-0,907\right)$. Berdasarkan hasil yang 
didapat, skor harga diri subjek dapat dibagi dalam empat kategori, yang dipaparkan dalam Tabel 2. Sedangkan skor kualitas hidup subjek yang didapat, dapat dibagi dalam empat kategori, yang terdapat dalam Tabel 3.

Berdasarkan hasil analisa statistik menggunakan Kolmogorov Smirnov terlihat bahwa sebaran data variabel harga diri memenuhi asumsi normalitas dengan hasil signifikansi 0,804. Sedangkan variabel kualitas hidup pun memenuhi asumsi normalitas dengan hasil signifikansi 0,05 . Uji normalitas yang terpenuhi membuat hipotesis penelitian diukur dengan menggunakan uji statistik parametrik menggunakan korelasi Pearson.

Tabel 2.

Kategorisasi Harga Diri

\begin{tabular}{lc}
\hline \multicolumn{1}{c}{ Kategori } & $\begin{array}{c}\text { Jumlah } \\
\text { Sampel }\end{array}$ \\
\hline Kategori Sangat Rendah (Skor 10-20) & 0 \\
Kategori Rendah (Skor 20-30) & 8 \\
Kategori Tinggi (Skor 30-40) & 20 \\
Kategori Sangat Tinggi (Skor 40-50) & 6 \\
\hline
\end{tabular}

Tabel 3.

Kategorisasi Kualitas Hidup

\begin{tabular}{lc}
\hline \multicolumn{1}{c}{ Kategori } & $\begin{array}{c}\text { Jumlah } \\
\text { Sampel }\end{array}$ \\
\hline $\begin{array}{l}\text { Kategori Sangat Rendah } \\
\text { (Skor 36 - 68,75) }\end{array}$ & 3 \\
Kategori Rendah (Skor 68,75 - 101,5) & 2 \\
Kategori Tinggi (Skor 101,5 - 134,25) & 14 \\
Kategori Sangat Tinggi & 15 \\
(Skor 134,25 - 167) & \\
\hline
\end{tabular}

Berdasarkan statistik deskriptif didapatkan bahwa skor harga diri rata-rata subjek berada pada kategori tinggi dengan kualitas hidup pada kategori sangat tinggi. Uji korelasi menggunakan pearson correlation, diketahui bahwa nilai korelasi pearson $=0,417$ dan signifikansi 0,014 . Nilai signifikansi sebesar 0,014 atau lebih kecil dari 0,05 menandakan bahwa terdapat korelasi antara variabel harga diri dengan kualitas hidup pada pasien $C K D$ yang menjalani hemodialisis. Koefisien korelasi pearson sebesar 0,417 menunjukkan adanya korelasi positif moderate. Dengan demikian dapat diambil kesimpulan bahwa kenaikan tingkat harga diri pada pasien CKD yang menjalani hemodialisis akan meningkatkan kualitas hidupnya.

Berdasarkan hasil penelitian, maka didapatkan hasil bahwa harga diri berkorelasi moderat dengan kualitas hidup pada pasien $C K D$ yang menjalani hemodialisis. Hal ini didukung oleh penelitian yang dilakukan oleh Farshi, Sharifi, dan Rad (2013) juga membuktikan bahwa adanya hubungan yang signifikan antara harga diri dan kualitas hidup. Gerogianni dan Babatsikou (2014) dalam penelitiannya juga menjelaskan bahwa pasien $C K D$ memiliki harga diri yang rendah terkait dengan kualitas hidupnya. Hal tersebut dijelaskan bahwa pasien $C K D$ yang mengalami hemodialisis mengalami keterbatasan fisik yang membuat mereka menjadi kurang produktif, misalnya dalam melakukan aktivitas sehari-hari sampai dengan hubungan seksual.

Berdasarkan teori self-determination, autonomy (kemandirian) adalah kebutuhan paling mendasar dari seseorang yang akan berpengaruh pada kesejahteraan hidup sehari-hari dan psychological well being. Saat kebutuhan autonomy tidak terpenuhi, maka akan menyebabkan rendahnya harga diri dan kondisi psikologis yang buruk (Ryan, Brown, Paradise Kernis dalam Gerogianni \& Babatsikou, 2014). Hal tersebut dikarenakan tidak jarang pasien yang mengalami CKD tidak dapat melakukan aktivitas sehari-harinya karena kondisi kesehatan mereka. Namun pada pasien $C K D$ yang dapat mengelola dan meningkatkan perawatan diri mereka dapat membuat kehidupan mereka semakin berharga, sehingga dapat dikatakan pula bahwa hal tersebut adalah salah satu dari hal-hal yang paling dibutuhkan pada 
pasien CKD (Jansen, Rijken, Heijmans, Kaptein, \& Groenewegen. 2012). Dilihat dari data demografi, usia rata-rata subjek 26-30 dimana berada pada masa produktif namun telah menjadi pasien $C K D$ yang diwajibkan untuk hemodialisis, sehingga menjadi membatasi produktivitas mereka. Hal ini terkait dengan autonomy yang semakin berkurang di saat usia mereka masih produktif.

Korelasi positif antara harga diri dengan kualitas hidup dapat dijelaskan pula bahwa kualitas hidup juga dikarakteristikkan dengan kondisi psikologis yang stabil termasuk harga diri (WHOQL-BREF, 1996). Selain itu, kualitas hidup juga dapat dipengaruhi oleh aspek psikologis atau emosi, sehingga adanya pengaruh negatif dari kondisi fisik yang menurun terdapat berupa emosi yang tidak stabil. Pada akhirnya emosi-emosi negatif dapat semakin mempengaruhi harga diri (Fallowfield, 2009). Korelasi yang hanya berada dalam taraf sedang dapat disebabkan karena kualitas hidup tidak hanya ditentukan oleh kondisi psikologis seperti harga diri, namun juga kualitas kesehatan fisik, hubungan sosial, dan lingkungan (WHOQL-BREF, 1996).

Berdasarkan data demografi, dapat dilihat bahwa subjek memiliki kualitas hidup yang sangat tinggi. Hal tersebut dapat dipengaruhi oleh frekuensi rata-rata subjek menjalani hemodialisis rutin sesuai anjuran dokter dalam seminggu 2 kali. Berdasarkan penelitian oleh Septiwi (2010) menemukan bahwa pasien yang mencapai adekuasi hemodialisis (terapi hemodialisis berhasil dan mencapai dosis yang diharapkan) memiliki peluang untuk mendapatkan kualitas hidup yang baik. Selain itu, harga diri yang tinggi dapat dipengaruhi oleh kondisi kualitas kesehatan yang baik sebagai hasil dari adekuasi hemodialisis, sehingga tidak terlalu mengganggu produktivitas sehari-hari. Menurut WHOQL-BREF (1996) salah satu domain yang menentukan kualitas hidup adalah kesehatan fisik. Hal tersebut juga diperkuat dalam penelitian ini yang menemukan sebanyak $38,1 \%$ subjek menilai kesehatannya dalam kondisi yang baik, $38,1 \%$ biasa saja, $19 \%$ buruk, dan $4,8 \%$ sangat baik. Kondisi kesehatan fisik yang baik akan membuat kualitas hidup pada pasien $C K D$ meningkat. Berdasarkan hasil penelitian terdapat $69 \%$ subjek yang tidak mengalami depresi atau cemas yang dapat mengganggu kegiatan sehari-harinya. Selain itu juga ditemukan terdapat $76,2 \%$ subjek yang tidak mengalami depresi atau cemas yang mengakibatkan tidak mampu bekerja.

Hasil penelitian juga menunjukkan bahwa harga diri pasien berada pada kategori tinggi, bahkan kualitas hidup pasein mayoritas pada kategori sangat tinggi. Hal tersebut berbeda dengan penelitian Gerogianni dan Babatsikou (2014) yang menjelaskan bahwa pasien CKD kurang memiliki harga diri karena adanya kesulitan untuk menjalankan aktivitas seperti sehari-hari atau aktivitas sosial lain dan tidak terpenuhinya kebutuhan otonomi yang dimiliki. Berbeda pula dengan hasil penelitian Mailani (2015) yang menyebutkan bahwa kualitas hidup pasien CKD yang menjalani hemodialisis lebih buruk dibandingkan dengan individu pada umumnya.

Temuan yang berbeda dalam penelitian ini dapat dipengaruhi oleh keikutsertaan mereka sebagai anggota dalam suatu komunitas yakni HGM (Hidup Ginjal Muda), sehingga mendapatkan social support dari sesama pasien maupun caregiver. Schoon (2006) menjelaskan bahwa konteks sosial yang lebih luas dapat menghasilkan sumber utama dukungan. Terdapat bukti yang menjelaskan mengenai pentingnya kekuatan komunitas yang positif, seperti bentuk dukungan atau kohesi dan sense of belonging pada komunitas tertentu. Salah satu aspek yang diungkapkan oleh Maslow (dalam Alwisol, 
2009) adalah respect from others, yang berarti adanya aspek penerimaan, apresiasi atau sekedar dikenal baik oleh orang lain, telah dapat menyumbang tingkat harga diri individu. Hal tersebut menunjukkan bahwa keikutsertaan pasien CKD dalam suatu komunitas berkontribusi pada harga diri maupun kualitas hidupnya.

Hasil tersebut sejalan dengan penelitian yang dilakukan oleh Petra \& Ronald (2003) pada pasien ginjal kronis dimana social support berkorelasi positif dengan harga diri yang lebih tinggi dan meningkatkan optimisme serta mampu menurunkan depresi. Lebih lanjut, dijelaskan bahwa belonging support dapat meningkatkan optimisme dan menurunkan depresi pada pasien CKD. Hasil penelitian tersebut juga sejalan dengan penelitian yang dilakukan oleh Silva, Braido, Ottaviani, Gesualdo, Zazzetta, Orlandi (2016) pada pasien CKD yang menjalani hemodialisis bahwa social support dapat meningkatkan kepuasan pasien pada perawatan hemodialisis yang dijalaninya serta meningkatkan kualitas hidup terutama terkait dengan fisiknya. Oleh sebab itu, hasil penelitian yang menunjukkan bahwa pasien memiliki harga diri yang berada pada kategori tinggi dan kualitas hidup yang mayoritas pada kategori sangat tinggi dapat dipengaruhi oleh adanya social support yang baik, sehingga pasien merasa hidupnya tetap positif meskipun mengalami sakit.

\section{SIMPULAN}

Kesimpulan dari penelitian ini adalah terdapat hubungan positif antara harga diri dengan kualitas hidup pada pasien $C K D$ yang menjalani hemodialisis $(r=0,417 ; p=$ 0,014). Walaupun demikian, hubungan antara harga diri dan kualitas hidup berada pada kategori moderate karena terdapat faktor-faktor lain yang dapat mempengaruhi kualitas hidup. Faktorfaktor lain bisa disebabkan oleh kualitas kondisi kesehatan, lingkungan, dan hubungan sosial. Saran bagi penelitian selanjutnya adalah menjadikan hasil penelitian ini untuk pilot study sebagai bahan untuk membuat intervensi bagi pasien $C K D$ yang menjalani hemodialisis. Selain itu, bisa dilakukan penelitian lanjutan untuk mengukur faktor-faktor lainnya yang dapat mempengaruhi kualitas hidup agar mendapatkan gambaran keseluruhan mengenai kondisi psikologis pasien $C K D$ yang menjalani hemodialisis.

\section{DAFTAR PUSTAKA}

Alam, S. \& Hadibroto, I. (2007). Gagal ginjal. Jakarta: PT Gramedia Pustaka Utama.

Alwisol. (2009). Psikologi kepribadian. Malang: UMM Press.

Babatunde, O., \& Forsyth, J. (2015). Lifestyle exercises for bone health and health-related quality of life among premenopausal women: A randomised controlled trial. Global Health Promotion, 23(3), 63-71, doi:10.1177/1757975914568901.

Badan penelitian dan pengembangan kesehatan kementerian kesehatan RI. (2013). Riset kesehatan dasar. Jakarta: Kementerian Kesehatan RI.

Baron, R. A., \& Byrne, D. (2004). Social psychology. Jakarta: Erlangga.

Cruz, M. C., Andrade, C., Urrutia, M., Draibe, S., Martins, L. A. N., \& Sessol, R. D. C. C. (2011). Quality of life in patients with chronic kidney disease. Journal of Clinics, 66(6), 991-5.

Fallowfield, L. (2009). What is quality of life? Susex: Hayward Medical Communication.

Farshi, M. G., Sharifi, H. P., \& Rad, M. A. (2013). The relationship between self-esteem, mental health and quality of life in patients with skin 
diseases. Asian Journal of Medical and Pharmaceutical Researches, 3(2), 50-54.

Farida, A. (2010). Pengalaman klien hemodialisis terhadap kualitas hidup dalam konteks asuhan keperawatan di RSUP Fatmawati Jakarta (Tesis tidak dipublikasikan). Fakultas Ilmu Keperawatan Universitas Indonesia, Depok, Indonesia.

Gerogianni, S. K., \& Babatsikou, F. P. (2014). Psychological aspects in chronic renal failure. Health Science Journal, 8(2), 205-210.

Gooz, M. (2012). Chronic kidney disease. Croatia: Intech.

Guindon, M.H. (2010). Self-esteem across the lifespan. New York: Taylor and Francis Group, LCC.

Hays, R. D., Kallich, J. D., Mapes, D. L., Coons, S. J., Amin, N., Carter, W. B., dkk. (1997). Kidney Disease Quality of Life Short Form (KDQOLSFTM), Version 1.3: A Manual for Use and Scoring. RAND.

Jansen, D. L., Rijken, M., Heijmans, M. J. W. M., \& Groenewegen, P. P. (2012). Psychological and social aspects of living with chronic kidney disease, chronic kidney disease and renal transplatation. Prof. Manisha Sahay (Ed.), InTech, DOI: 10.5772/25992. Diunduh dari http://www.intechopen.com/books/ch ronic-kidney-disease-and-renaltransplatation/psychological-andsocial-aspects-of-living-withchronic-kidney-disease.

Kementrian Kesehatan RI. (2014). Situasi kesehatan jantung. Jakarta: Kementrian Kesehatan RI.

Lew, S.Q., \& Piraino, B. (2005). Psychosocial factors in patients with chronic kidney disease: Quality of life and psychological issues in peritoneal dialysis patients. Journal of Seminars in Dialysis, 18(2), 119123. doi: $10.1111 / \mathrm{j} .1525-$ 139X.2005.18215.x.

Mailani, F. (2015). Kualitas hidup pasien penyakit ginjal kronik yang menjalani hemodialisis: Systematic review. Ners Jurnal Keperawatan, 11(1), 1-8.

Mardyaningsih, D.P. (2014). Kualitas hidup pada penderita gagal ginjal kronik yang menjalani terapi hemodialisis di RSUD dr. Soediran Mangun Sumarso Kabupaten Wonogiri (Skripsi tidak dipublikasikan). Fakultas Ilmu Keperawatan STIKES Kusuma Husada, Surakarta, Indonesia.

Petra, S., \& Ronald, F. (2003). The influence of social support and problematic support on optimism and depression in chronic illness: A prospective study evaluating selfesteem as a mediator. Journal of Health Psychology, 22(2), 123-129. doi:10.1037/0278-6133.22.2.123.

Putri, Y. S., \& Yadi, D. F. (2014). Blok aksilar pada pasien pseudoaneurisma pada antebrakii sinistra yang disertai gagal ginjal terminal. Jurnal Anestesi Perioperatif, 2(1), 79-84.

Poorgholami, F., Javadpour, S., Saadatmand, V., \& Jahromi, M. K. (2015). Effectiveness of self-care education on the enhancement of the self-esteem of patients undergoing hemodialysis. Global Journal of Health Science, 8(2), 132-136, doi: 10.5539/gjhs.v8n2p132.

Perkumpulan Nefrologi Indobnesia (PENEFRI). (2014). 7th report of Indonesian renal registry. Bandung: PENEFRI. 
Rosenberg. (1965). The Self-Esteem Scale.

Schoon, I. (2006). Risk and resilience adaptation in changing times. New York: Cambrige University Press.

Septiwi, C. (2010). Hubungan antara adekuasi hemodialisis dengan kualitas hidup pasien hemodialisis di unit hemodialisis $R S$ Prof. $d r$. Margono Soekarjo Purwokerto (Tesis tidak dipublikasikan). Fakultas Ilmu Keperawatan Universitas Indonesia, Depok, Indonesia.

Shdaifat, E. A., \& Manaf, M. R. A. (2012). Quality of life of caregiver and patients undergoing haemodialysis at ministry of health, Jordan. International Journal of Applied Science and Technology, 2(3), 75-85.
Silva, S. M. D., Braido, N. F., Ottaviani, A. C., Gesualdo, G. D., Zazzetta, M. S., \& Orlandi, F. D. S. (2016). Social support of adults and elderly with chronic kidney disease on dialysis. Journal of evista Latino-Americana de Enfermagem, 24 . doi: 10.1590/1518-8345.0411.2752.

WHOQOL Group. (1997). The world health organization quality of life instruments. 